\title{
Lejla Bušatlić
}

\section{BOSANSKI SLOG U KOMPARATIVNOM DISKURSU NACIONALNIH ARHITEKTONSKIH STILOVA NA PODRUČJU BALKANA}

U članku se analizira problematika arhitekture bosanskog sloga kroz osvrt na fenomen nacionalnog arhitektonskog stila, njegove uloge u konstrukciji nacionalnog identiteta, političke i ideološke instrumentalizacije. Otvara se pitanje odnosa tradicije i modernosti te pozicije graditeljskog naslijeđa u suvremenom kontekstu. Problemski okvir interpretacije specifičnosti nacionalnog arhitektonskog idioma obuhvaća i diskurzivni pogled na odnos periferije i centra. Kroz komparativnu analizu nacionalnih stilova u arhitekturi balkanskih zemalja poput Bosne i Hercegovine, Turske, Hrvatske i Srbije definira se njihov karakter, distinkcija i međusobne poveznice. Arhitektura bosanskog sloga promatra se u njenom razvojnom toku kao arhitektonski idiom nacionalnog predznaka, ali i autentična stilska odrednica nastala u procesu kreativnog istraživanja graditeljskog naslijeđa, koje će, u konačnici, rezultirati novim prostorno-oblikovnim i estetskim vrijednostima, sukladnim modernističkim arhitektonskim konceptima. U tom smislu, propituje se pozicija bosanskog sloga kao nacionalnog stila u povijesti evropskog modernizma, njegove poveznice s estetikom moderne, utemeljene na principima reduciranja suvišne dekorativnosti, oblikovnog purizma i funkcionalizma.

Ključne riječi: bosanski slog, nacionalni arhitektonski stil, srpsko-bizantski stil, modernizam, tradicija, prvi nacionalni arhitektonski pokret, nacionalni identitet

\section{UVOD}

Dosadašnja znanstvena istraživanja bosanskog sloga ukazuju na to da se radi o autentičnoj pojavi koja otvara prostor za razvoj arhitektonske misli i prakse, uspostavljajući poveznice s modernističkim tendencijama kroz analitički pristup graditeljskom naslijeđu. Stoga, ovu inovativnu pojavu u bosanskohercegovačkoj arhitekturi treba promatrati kao rezultat kritičkog 
promišljanja tradicionalnih oblika i njihovog prilagođavanja suvremenom kontekstu.

Znanstveno-istraživački rad Nedžada Kurte od iznimne je važnosti za razumijevanje ovog fenomena. On daje cjelovit uvid u razvojni tok i suštinske odrednice novog arhitektonskog stila, promatrajući širu sliku povijesnog, znanstvenog i umjetničkog prožimanja zapadne i orijentalne kulture. Ibrahm Krzović u svojoj studiji bosanskohercegovačke arhitekture secesijskih stilskih obilježja prezentira specifičnosti arhitekture bosanskog sloga i njegove poveznice s modernističkim tendencijama. Kroz analizu opusa Josipa Pospišila, Mehmed Hrasnica ukazuje na doprinos arhitekte razvoju ideje o oblikovanju novog arhitektonskog idioma i njegov kreativan pristup reinterpretaciji tradicionalnih formi.

Cilj rada je kroz interdisciplinarni pristup sagledati problematiku u širem kontekstu te ukazati na različitosti između bosanskog sloga i nacionalnih stilova definiranih historicističkim pristupima arhitekturi s generaliziranim percepcijama orijentalnih tradicija. Ono što bi se moglo izdvojiti kao izvorni znanstveni doprinos rada je prezentiranje novih činjenica i širenje znanstvenih spoznaja o arhitekturi bosanskog sloga, sagledavanje, sistematizacija i problemsko proširivanje fenomena novog arhitektonskog idioma u kontekstu arhitekture evropske Moderne i modernizma.

\section{ARHITEKTURA BOSANSKOG SLOGA, STVARALAČKA SINTEZA TRADICIONALNOG I SUVREMENOG}

Traganje za nacionalnim stilom $\mathrm{u}$ arhitekturi austrougarskog razdoblja obilježila su dva pristupa koji se manifestiraju u formi importiranog neomaurskog stila, bez poveznica s lokalnim arhitektonskim tradicijama i bosanskog sloga nastalog u procesima kreativnog istraživanja bosanskohercegovačkog graditeljskog naslijeđa. Pitanje konstrukcije bosanske nacije, aktualizirano u periodu austrougarske uprave, generiralo je oblikovanje nacionalnog arhitektonskog stila, koji će biti u funkciji demonstracije postojećih odnosa dominacije imperijalne moći i stvaranja novog identiteta.

Kállayeva ideja o interkonfesionalnoj bosanskoj naciji imala je cilj, prije svega, neutraliziranje nacionalizma susjednih zemalja, implicirajući 
definiranje odgovarajućeg arhitektonskog stila u okviru historicističkih tendencija. Neomaurski stil odabran je kao adekvatan pristup s jasnim referencama na islamsku umjetnost. Arhitektonska forma se instrumentalizira s ciljem prezentiranja ideje imperijalizma kao nositelja prosperiteta u perifernim sredinama koje ne pripadaju zapadnoevropskom civilizacijskom krugu. Jedno od obilježja neomaurskog stila je projekcija novog političkog narativa fokusiranog na prikaz različitosti okupirane zemlje $u$ odnosu na ostatak Evrope.

Evropocentrično obrazovanje arhitekata, obilježeno pretjeranim generalizacijama ideje orijentalnog, rezultiralo je arhitektonskim kompozicijama oblikovanim bez razvijenog osjećaja za duh mjesta i ambijentalne vrijednosti autohtonog graditeljskog naslijeđa. Ova stilska odrednica, pored doslovnog transponiranja elemenata islamske umjetnosti, ima neosporno dokumentarnu vrijednost i lokalnu važnost kao primjer arhitektonskog stila koji dobiva ključnu ulogu u konstrukciji interkonfesionalnog nacionalnog identiteta. Analizirajući izvorišta arhitekture bosanskog sloga, Kurto (1998, str. 38) zaključuje da, iako neomaurska arhitektura predstavlja romantizmom potaknut primjer arhitekture eklekticizma, ona u određenim segmentima raskida s akademizmom i otvara mogućnosti za razvoj arhitektonske misli. Stoga je treba promatrati kao važnu kariku u kontinuitetu razvojnih procesa, usmjerenih k oblikovanju nacionalnog stila, koji će, u konačnici, rezultirati pojavom moderne.

Kao primjer arhitektonskog rješenja koje povezuje neomaurski stil s elementima bosanskohercegovačkog graditeljskog naslijeđa Kurto (1998, str. 256) navodi projekt muslimanske čitaonice u Sarajevu Josipa Vancaša. Dogradnja drvene verande, kao reminiscencija na divanhane i kamerije, na građevini s prepoznatljivim odlikama neomaurskog stila prvi je primjer izravnog oslanjanja na tradiciju lokalnog graditeljstva i interpretacija određene arhitektonske teme. Ovaj vid Vancaševe intervencije u sklopu već realiziranog projekta neomaurskih stilskih orijentacija ukazuje na promjenu paradigme $\mathrm{u}$ valorizaciji i percepciji lokalnog graditeljstva. Svoj kritički osvrt glede nastojanja da se bosanskohercegovačko graditeljsko naslijeđe transformira po uzoru na srednjoevropske modele, kroz arhitektonske prakse utemeljene na importiranim neostilovima, Vancaš (1928, str. 353-356) iskazuje riječima u kojima i sam priznaje zabludu svih odgovornih koja je dovela do neadekvatnih urbanističkih i arhitektonskih rješenja: 
Glede spoljašnjosti novih zgrada u Bosni griješilo se dugo, griješila je Zemaljska vlada, griješile su oblasti, a griješio sam i ja.

Za oblikovanje novog arhitektonskog stila koji je otvorio put razvoju modernističkih tendencija od presudne je važnosti bio stvaralački i istraživački pristup tradicionalnom graditeljstvu. Interes za naslijeđene arhitektonske forme može se promatrati kroz politički diskurs i prezentiranje bosanskohercegovačkog naslijeđa na međunarodnim i svjetskim izložbama. Studij umjetničke baštine Bosne i Hercegovine potican je zvaničnom kulturnom politikom kojom se kroz naglašavanje kulturnog težilo k ostvarivanju nacionalnog identiteta. Kao primjer različitih stilskih obilježja preuzetih iz islamske umjetnosti, kolažirane arhitekutre s reminiscencijama na tradicionalne forme lokalnog graditeljstva, izdvajaju se arhitektonska rješenja bosanskohercegovačkih paviljona na međunarodnim izložbama.

Analizirajući ovu problematiku, Kurto (1998, str. 49) ukazuje na značaj Jubilarne izložbe u Beču iz 1898. godine, obilježene utjecajem stila secesije. Stanovita kompatibilnost biomorfne stilizirane i plošne islamske dekoracije te secesijskog shvatanja nove uloge ornamenata dovode do zanimljivog spoja u arhitektonskom rješenju Josepha Urbana za paviljon Zemaljske vlade u sklopu pomenute izložbe. Od posebne važnosti za prezentaciju bosanskohercegovačkog naslijeđa bila je Svjetska izložba u Parizu 1900. godine. U arhitektonskom rješenju bosanskog paviljona češkog arhitekte Karela Páneka mogu se prepoznati asocijacije na tradicionalnu stambenu arhitekturu u obliku kula i odžaka kroz pojedine segmente arhitektonske kompozicije, poput snažne piramide krova, doksatnih formi i drvene verande.

Arhitekturu bosanskih paviljona na međunarodnim i svjetskim izložbama Baotić (2012, str. 107-130) valorizira kao hibridne građevine, slobodne arhitektonske kreacije kojima je jedina zajednička crta ta da su bili generalizirani iskazi islamske graditeljske baštine. Oblikovanje arhitektonske kompozicije slobodnom upotrebom formi islamske arhitekture u funkciji je propagiranja značaja kulturne misije austrougarske uprave u Bosni i Hercegovini te stvaranju nove vrste identiteta. Autorica u zaključnim razmatranjima naglašava da su prikazi Bosne i Hercegovine na međunarodnim izložbama imali za cilj prezentirati progres koji je nova vlast postigla u oblasti ekonomije, prosvjete i kulture na okupiranim teritorijama. Baotić 
ističe da općenito bosanskohercegovačke izložbene paviljone karakterizira idiom islamske umjetnosti orijentalnog karaktera bez poveznice s tradicijom i autentičnim lokalnim naslijeđem, jer, osim Blažekove bosanske kuće u Budimpešti te Panekovog paviljona u Parizu, nijedan paviljon se ne oslanja izravno na bosanskohercegovačku graditeljsku tradiciju, već predstavlja asocijaciju na memlučku i maursku spomeničku baštinu. Međutim, takav će se pristup promijeniti početkom 20. stoljeća pod utjecajem modernističkih tendencija u arhitekturi secesije.

Pred kraj austrougarskog razdoblja potpuno se mijenja recepcija i odnos prema lokalnom graditeljstvu, na što ukazuju različitosti između bosanskog sloga i neomaurskog stila. Generalizirani pogled na Orijent s obilježjem romantizma i nastojanje da se kroz monumentalnu arhitektonsku formu prezentira kulturna politika Monarhije - zamijenile su studiozne analize graditeljskog naslijeđa, koje će, u konačnici, rezultirati složenim stilskim sintezama. Arhitektura bosanskog sloga je u svom kreativnom i istraživačkom konceptu bliža secesijskim formama iz kojih se razvija nego eklektičnim metodama neostilova bez razvijenog senzibiliteta za karakter i ambijentalne vrijednosti autohtonog graditeljstva. Školovani arhitekti, djelujući kao službenici Zemaljske vlade u Bosni i Hercegovini, imali su priliku temeljito se upoznati s lokalnom graditeljskom baštinom, u kojoj uočavaju niz oblikovnih, funkcionalnih i prostornih vrijednosti, podudarnih sa središnjim principima oblikovnog purizma i funkcionalizma moderne arhitekture. Ono što čini osobitost ovih istraživanja jeste činjenica da nije bila riječ o pukom aditivnom principu, već o kritičkom pristupu u dominantno modernističkoj paradigmi. Primjer tome pružaju arhitektonske skice i studije Ernsta Lichtblaua, studenta Otto Wagnera, koje je 1904. godind napravio u okolici grada Jajca. Prepoznajući oblikovne i prostorne vrijednosti tradicionalne bosanske kuće, on nastoji doći do stila kojim bi ista bila usklađena potrebama suvremenog života (Krzović, 2004, str. 190). Ovakav kreativni pristup bio je sasvim suprotan do tada dominantnoj paradigmi romantizirane i generalizirane precepcije Orijenta, koja je svoje manifestacije u arhitekturi imala u oživljavanju neostilova, prije svega - neomaurskog.

Na značaj utjecaja bečkog kulturnog kruga u oblikovanju novog arhitektonskog stila ukazuje Kurto (1998, str. 142), jer su, upravo na tragu istraživanja Wagnerove škole, teme genius loci, strani arhitekti prepoznali vrijednost i 
izvornost tradicionalnog graditeljstva. Kako bi se mogli razumjeti složeni procesi međusobnih prožimanja secesije, bosanskog sloga i moderne, nužno je imati u vidu ovu vrstu referiranja na suvremene tendencije iz Beča.

Djelovanje arhitekata Josipa Vancaša i Pospišila imalo je presudnu ulogu u promjeni percepcije bosanskohercegovačkog graditeljskog naslijeđa. Teorijske okvire novog arhitektonskog idioma i naziv bosanski slog definira Vancaš (1928, str. 353-356), potaknut zapažanjima holandskog ministra građevinarstva i povjesničara umjetnosti Corneliusa Gurlitta o važnosti narodnog graditeljstva i očuvanja njegove autentičnosti, koje su iznijeli prilikom posjete Sarajevu.

Sa stanovišta analize nacionalnog stila u arhitekturi i istraživačkog pristupa graditeljskom naslijeđu, znakovita su Pospišilova promišljanja ovih fenomena. Dajući cjelovit prikaz opusa ovog arhitekte, Hrasnica (2003, str. 181-258) donosi i prijevode njegovih tekstova objavljenih u stručnim časopisima. Problemski okvir Pospišilovih tekstova i izlaganja koje je prezentirao u Tehničkom klubu ukazuje na to da autor u narodnom graditeljstvu prepoznaje univerzalne vrijednosti, te ih nastoji interpretirati $\mathrm{u}$ suvremenom kontekstu. On se snažno zalaže za afirmaciju narodnog stila u graditeljstvu, naglašavajući originalnost i spontanu stvaralačku logiku koja proističe iz duha naroda. Stavove o ovoj problematici iznosi u tekstu $O$ graditeljskoj umjetnosti s osvrtom na naše odnose koji zaključuje s određenjem karaktera vanjskog oblika umjetničkog djela kao tradicije domaće umjetnosti $i$ narodnog karaktera, bez lažnosti $i$ bez polovičnosti jer umjetnost može pružiti samo ono što je sadržano u duši naroda i ništa drugo (Hrasnica, 2003, str. 241-244).

Smatra da autentičnost arhitektonskog izraza karakterističnog za narodno graditeljstvo treba promatrati kao povijesnu podlogu, inspirativni poticaj i putokaz u oblikovanju novih arhitektonskih formi, a ne preferirati internacionalni stil koji definira kao arhitekturu bez karaktera. Analizirajući obilježja narodnog graditeljstva, prepoznaje njegov kontinuitet u procesima transkribiranja naslijeđenih oblika u leksik moderne arhitekture, navodeći primjere iz opusa arhitekata Josepha Maria Olbricha i Josepha Hoffmana, i na taj način povlači jasne paralele između bosanskohercegovačke tradicionalne arhitekture i estetike modernizma. 
Uvid u djelatnost renomiranih arhitekata iz austrougarskog razdoblja ukazuje da novi arhitektonski idiom nije nastao kao rezultat političkih stremljenja i jačanja nacionalne svijesti, već je oblikovan u procesima kritičkog promišljanja dotadašnje arhitektonske prakse, utemeljene na importiranim stilskim obrascima $\mathrm{i}$ istraživanjima tradicionalnih arhitektonskih oblika. Kurto (1998, str. 264) ovu specifičnu pojavu u bosanskohercegovačkoj arhitekturi ne definira kao nacionalni arhitektonski idiom, već stil regionalnog karaktera, jer je regionalna posebnost uvjetovala terminološku odrednicu bosanski slog. Tome u prilog navodi Vancaševe projekte za zgradu Pravoslavne crkvene opštine kao natječajni rad iz 1910. godine i Hrvatskog doma u Kiseljaku, realizirane u čistom bosanskom slogu, bez dodatnih nacionalnih obilježja.

Autor naglašava da je za interpretaciju jedne umjetničke pojave kao što je bosanski slog nužno sagledati i paralelno analizirati filozofske stavove zapadne kulture i islama. Ako novi arhitektonski stil promatramo kroz diskurs međusobnog prožimanja istočnog i zapadnog civilizacijskog kruga, zaključujemo da bosanski slog nije rezultat prisilno ujedinjenih različitosti, već predstavlja spoj kultura koje su se dopunjavale kroz povijest. U propitivanju susretanja različitih kulturoloških obilježja, Kurto (1998, str. 161-164) se referira na ideje Oswalda Spenglera koje se baziraju na diskontinuitetu, nekomunikativnosti kultura i pojavi pseudomorfoze kao tendencije upotrebe pozajmljenih formi koje zatomljavaju vitalitet jedne kulture. Stoga se importirana arhitektura historicizma u Bosni i Hercegovi može smatrati pseudomorfozom. Na taj je način napravljena jasna distinkcija između historicizma neostilova kao nametnutih oblika dominantne kulture i bosanskog sloga kao originalnog arhitektonskog izraza koji potvrđuje kontinuitet bosanskohercegovačkog graditeljskog naslijeđa.

Dva su izvorišta za oblikovanje novog arhitektonskog stila: arhitektura secesije i tradicionalne forme bosanskohercegovačke stambene arhitekture iz osmanskog perioda. Uspostavljanjem dijaloškog odnosa između tradicije i modernosti, utemeljenog na principima nenametljive integracije arhitekture i prirode, prava na vidik, polivalentne funkcionalnosti unutarnjih prostorija, redukcionizma dekorativnosti i sažimanja forme, definiran je novi arhitektonski idiom. 
Istražujući podudarnosti između arhitekture secesije i naslijeđenih arhitektonskih oblika, Kurto (1998, str. 54) otkriva specifične forme tradirane secesije u kojima prepoznaje nagovještaje bosanskog sloga i rane moderne. Smatra da se duh umjetnosti secesije najbolje izrazio u stambenoj arhitekturi te u toj tipologiji uočava paralelizme s tradicionalnim oblicima. Analizirajući ovaj fenomen, Kurto (1998, str. 243) kao poveznice između modernog i tradicionalnog izdvaja upotrebu islamskih dekorativnih elemenata i doksatih formi u secesijskim arhitektonskim rješenjima. Doksat se u kontekstu pojave tradirane secesije u Bosni i Hercegovini oslanja na uzore autohtonog graditeljskog naslijeđa. Problematizirajući doksatne forme kao zajedničku karakteristiku stambene arhitekture stila secesije i naslijeđenih graditeljskih oblika, Kurto (1998, str. 243) zaključuje da se primjenom doksata s koncentracijom otvora, fakturom materijala i proporcijama oblikuju arhitektonska rješenja koja u sebi nose prepoznatljive odlike duha mjesta. Kao primjer građevine secesijskih stilskih obilježja, koja ima izrazito visok stupanj interpretacije duha tradicionalne arhitekture, Kurto (1998, str. 246) izdvaja stambenu dvokatnu zgradu Mehmeda-bega Fadilpašića u Sarajevu iz 1910. godine.

Stilske karakteristike ove stambeno-graditeljske cjeline Krzović (2004, str. 197), u sklopu analize razvoja bosanskohercegovačke arhitekture secesije, interpretira kao arhitekturu bosanskog sloga. Oba autora na osnovu načina modelacije, stilizacije i ritmizacije dekorativnih oblika u rješenju fasade prepoznaju arhitektonski rukopis Rudolfa Tönniesa. Na osnovu ovakvih primjera može se zaključiti da se nastanak novog arhitektonskog idioma izravno oslanja na secesijsku metodu građenja stilskog izraza te da je isti znak svog vremena i odraz visoke svijesti o važnosti i vrijednosti kulturnog konteksta u kojem djelo nastaje.

Svojim čistim geometrijskim formama, jednostavnim rješenjima fasada i reduciranjem secesijske dekorativnosti - arhitektura bosanskog sloga može se označiti kao početak moderne u bosanskohercegovačkoj arhitekturi. Ovaj je arhitektonski izraz suštinski moderan, formalno secesijski, a oblikovno prepun asocijacija na tradicionalnu arhitekturu.

Definiranjem arhitekture bosanskog sloga kao sinteze tradicije i modernosti, Kurto (1998, str. 280) ukazuje da su u tradicionalnim arhitektonskim formama tražene one univerzalne vrijednosti koje promovira i avangardna 
arhitektura. Vancašev projekt iz 1913. godine za obiteljsku kuću Husedžinovića u Banjoj Luci predstavlja izvanredan primjer novog arhitektonskog idioma u kojem se prepoznaju nagovještaji modernizma. Kreativni istraživački pristup graditeljskom naslijeđu nastavlja se u razdoblju moderne i postmoderne, a potvrdu tome pronalazimo u opusima bosanskohercegovačkih arhitekata: Reufa i Muhameda Kadića, Juraja Neidhardta, Zlatka Ugljena i Amira Vuka.

Bosanskohercegovačka arhitektura moderne i bosanski slog kao njena anticipacija rezultat su složenog procesa transformacije orijentalnog civilizacijskog kruga u zapadni koji se reflektirao i u područjima društveno-ekonomskih odnosa. Imajući u vidu višeznačnost novog arhitektonskog idioma, njegovo pozicioniranje u okvire nacionalnog stila značilo bi sagledavanje problematike sa jednog stajališta, koje ne može dati cjelovit uvid u specifičnost fenomena. Stoga, arhitekturu bosanskog sloga ne treba razumijevati i tumačiti isključivo kroz politički diskurs kao umjetničku formu dominantnih nacionalnih obilježja, već kao rezultat kreativnog pristupa $\mathrm{u}$ traganju za mogućnostima reinterpretacije tradicionalnih oblika.

\section{KOMPARATIVNA ANALIZA PROBLEMATIKE NACIONALNOG ARHITEKTONSKOG STILA NA PODRUČJU BALKANA}

Kako bi se sagledale sve posebnosti bosanskog arhitektonskog stila, nužno je napraviti komparativnu analizu u odnosu na slične tendencije u okruženju i široj regiji Balkana. Nastojanja da se oblikuje turski nacionalni stil u arhitekturi početkom 20. stoljeća obilježila je aktivnost male grupe arhitekata koja je iskoristila povoljan povijesni trenutak uspostave nove vlasti kako bi ponudila odgovarajuće stilske odrednice, koje će se uspješno uklopiti u program nacionalnog preporoda.

Zadatak je bio složen jer je novi arhitektonski izraz morao napraviti otklon od klasične osmanske arhitekture, koja je u specifičnom političkom trenutku sekularizacije državnog uređenja percipirana reakcionarnom i istodobno pratiti suvremeni kontekst kroz prihvatanje stilskih odrednica arhitekture evropskog modernizma. Arhitekti su bili obazrivi u odabiru oblika koji su mogli imati negativne konotacije. Sukladno političkom 
kontekstu i nastojanjima Kemala Ataturka da izgradi sekularnu državu, klasični osmanski arhitektonski motivi nisu preferirani jer su bili politički nekorektni i sadržavali su vjerske aluzije. Nije bilo preporučljivo ni pretjerano oslanjanje na zapadnoevropska rješenja, tako da je najbolji odabir bilo referiranje na arhitektonske oblike iz seldžučke tradicije.

I pored svih tih ideoloških izazova i složenosti trenutka u kojem su djelovali i stvarali, arhitekti okupljeni oko ideje nacionalnog arhitektonskog stila uspješno su oblikovali složene arhitektonske kompozicije pod utjecajem suvremenih tendencija u razvoju moderne arhitekture s orijentalnim sklonostima dekorativnim elementima nacionalnog, ali ne nužno naglašenog islamskog karaktera. Njihov je pristup često povezivan s terminima neoklasični turski stil ili nacionalna arhitektonska renesansa. Konačna formulacija naziva za ovu specifičnu pojavu u povijesti recentnije turske arhitekture definirana je u akademskim krugovima izrazom koji se i danas koristi: Prvi arhitektonski nacionalni pokret.

Njegov vremenski okvir obuhvaća razdoblje od sedamnaest godina (19121929) unutar kojeg je realizirano niz značajnih arhitektonskih projekata u velikim urbanističkim središtima. Pored arhitekte Kemalettina Beya, školovanog u Berlinu, kao jednog od osnivača pokreta treba spomenuti i Vedata Teka, koji je svoju zvaničnu naobrazbu stekao u Parizu, a među onima koji su im se pridružili izdvajaju se imena Arifa Hikmet Koyunoglua i Giulija Mongerinija. Tempo njihovog rada u dvadesetim godinama 20. stoljeća bio je impozantan.

Projektirali su građevine reprezentativnog karaktera u svim većim gradovima na području Turske, poput Istanbula i Ankare. Osobito se ističu Mongerijeva arhitektonska rješenja, od kojih posebnu pažnju privlači zgrada sjedišta Ziraat banke koju Veselinović (2014) izdvaja kao najuspješniju autorovu realizaciju.

Za razliku od nacionalnih arhitektonskih stilova u Turskoj bosanski slog nije bio potaknut nacionalnim preporodom, niti strogo definiran specifičnim političkim momentom sekularizacije države kojem se morao prilagoditi. Ono što bi se moglo izdvojiti kao poveznica između bosanskog sloga i turskog nacionalnog stila $\mathrm{u}$ arhitekturi jesu jasne orijentacije prema modernističkim tendencijama evropske arhitekture i reinterpretacija tradicionalnih arhitektonskih oblika. 
U odrazu ideje romantizma i neostilova 19. stoljeća treba promatrati nastojanja da se definira srpski nacionalni stil u arhitekturi. Nakon niza lutanja i improvizacija traganja za nacionalnim stilom, koje su obilježile duže vremensko razdoblje od jednog stoljeća, u konačnici su ove težnje rezultirale arhitektonskim rješenjima sa snažnim referencama na prošlost, kroz evokaciju bizantskih tradicija. Nacionalni stil u Srbiji, kao specifičan vid i produžetak romantizma, imao je sopstvenu ideologiju s državnom podrškom, koja je u oživljavanju tradicionalnih formi vidjela mogućnost za duhovni preporod.

Aleksandar Kadijević u svom znanstveno-istraživačkom radu elaborira problematiku srpskog nacionalnog stila, koji se može definirati kao obnova bizantskih arhitektonskih tradicija, prije svega u oblasti sakralne arhitekture. Takav pristup oblikovanju novog arhitektonskog izraza, s nacionalnim predznakom i obilježjima eklekticizma, uvjetovan je razvojem bizantologije na području Srbije, što je rezultiralo širenjem znanstvenih spoznaja o slojevitoj genezi bizantske arhitekture. Kadijević (2016) ukazuje da se uočava poistovjećivanje vjerskog i nacionalnog identiteta koje je u srpskoj kulturi općenito ostavilo prepoznatljiv vizualni trag. Uz nastojanja da se ožive tradicionalni oblici graditeljskog naslijeđa, prisutan je i problem njegove suvremene reinterpretacije. Iako je paralelizam u revitalizaciji srednjovjekovnih arhitektonskih matrica i aktualnih evropskih stremljenja stvarao dojam o konfliktu unutar različitih stilskih odrednica, Kadijević (2016, str. 21) smatra da je prezentirao progresivnost i stremljenje k emancipaciji suglasnoj s težnjama nacionalnih pokreta u drugim evropskim kulturama.

Ignjatović (2016, str. 345), analizirajući srpsko-bizantski diskurs i ulogu arhitekture u konstrukciji nacionalnog identiteta, ukazuje na procese bizantinizacije i debizantinizacije, sagledavajući problematiku u širem kontekstu. Autor otvara pitanje uloge arhitekture u procesima jačanja ideološke strukture, nacionalizma, imperijalne vlasti i dominacije. Naglašava da je sistem slika o srpskoj nacionalnoj arhitekturi i njenom odnosu s bizantskom tradicijom, konstruiran kroz historiografske tekstove, bio mnogostruk, transformabilan i ideološki instrumentalan. Prisustvo različitih interpretacija i pristupa srpsko-bizantskom diskursu kroz naglašenu debizantinizaciju nacionalne prošlosti i njezin paralelizam s tezama o bizantinizaciji Ignjatović (2016, str. 90) promatra ne kao isključive, već komplementarne 
strategije oblikovanja nacionalnog narativa, ukazujući na to da se u oba slučaja radi o instrumentalizaciji Bizanta kao obligatornog kulturološkog repera, a ne pukog povijesnog objekta. Problematizirajući fenomen nacionalnih arhitektonskih stilova na području Balkana kroz diskurs evropskih kulturoloških utjecaja, autor smatra da je simultana nacionalizacija lokalne srednjovjekovne arhitekture i aproprijacija bizantskog imperijalnog naslijeđa, ugrađenih u različite okvire nacionalnih tradicija naroda Balkana, pružala potvrdu povijesnosti nacije i određivala sfere njezinog utjecaja i prostiranja, pozicionirajući je u okvire evropskih civilizacijskih krugova.

Kao ilustrativan primjer dinamike procesa asocijacija i disocijacija u odnosu na bizantske tradicije, Ignjatović (2016, str. 251) izdvaja arhitektonsko rješenje Svetosavskog hrama u Beogradu. Analizirajući pluralizam stilskih obilježja i način interpretacije konkursnih uvjeta, uočava dominaciju dva osnovna arhitektonska obrasca koji se vežu za arhitektonska rješenja Gračanice i Aja Sofije. Drugonagrađeni projekat Bogdana Nestorovića predstavljao je sažetak ovih dviju arhitektonskih tendencija. Autor ukazuje na to da se iza ove neobične inklinacije k najvećoj bizantskoj crkvi krila sasvim precizna uloga simboličke reprezentacije nacionalnog identiteta. Na temelju prezentiranih činjenica izvodi zaključak da ova građevina na simboličkoj razini nije predstavljala samo nacionalni spomenik Srba, već i potvrdu njihove nacionalne dominacije u novom jugoslavenskom kontekstu, kroz referiranje na bizantsko imperijalno naslijeđe.

U arhitekturi bosanskog sloga nije bilo primjera reinterpretacija reprezentativnih građevina sakralnog karaktera u funkciji instrumentalizacije arhitektonske forme s jasnom političkom porukom. Polazište i inspirativni poticaj za oblikovanje novog arhitektonskog idioma je tradicionalna bosanskohercegovačka stambena arhitektura, definirana humanim mjerilom. Kao općeprihvaćeni standard multireligijskog i multietničkog karaktera, ovaj tip gradnje, kao i arhitektura bosanskog sloga, nadilazi okvire nacionalnih odrednica. Prilagođavajući se novom društvenom kontekstu i suvremenim uvjetima stanovanja, bosanska kuća potvrđuje svoj vitalitet kroz arhitekturu bosanskog sloga i recentnija arhitektonska rješenja u kojima se prepoznaju oslanjanja na univerzalne vrijednosti graditeljskog naslijeđa.

Komparirajući nacionalne arhitektonske stilove, Kurto (1998, str. 281) ukazuje da se srpsko-bizantski stil u svojoj suštinskoj odrednici razlikuje od 
bosanskog sloga, jer se bazira na akademizmu i nije rezultirao izmjenama općeg sklopa građevinskog korpusa. Njegova inovativnost zadržala se u domenu dekorativnosti. Zaključuje da je to, u suštini, romantičarska arhitektura koja se može smatrati nacionalnom samo u prenesenom smislu, struktura koja uvjetno odgovara duhu zamišljene nacije.

Neomaurski i srpsko-bizantski stil kao propagandni instrumenti u funkciji imperijalnih ideologija imaju podudarnosti. Oba su stila jasno vezana za konstrukciju različitih nacionalnih identiteta, a u oblikovnom su smislu određeni eklektičnom metodom neostilova. Bosanski slog, neopterećen nacionalnim odrednicama, fokusiran je na konstruktivnu suštinu arhitekture i prostorno-oblikovne vrijednosti graditeljskog naslijeđa. Oslobođen političkih konotacija, rezultat je analitičkog promišljanja i stvaralačke rekontekstualizacije graditeljskog naslijeđa. U tom smislu, srpsko-bizantski i neomaurski stil, kao odrazi faksimilske interpretacije elemenata preuzetih iz prošlosti, nisu uspjeli ostvariti takav vid kreativnih stilskih sinteza uspostavljanjem poveznica između tradicije i modernosti poput bosanskog sloga.

Analizirajući problematiku nacionalnog arhitektonskog stila u Hrvatskoj i doprinos Isidora Kršnjavija u oblikovanju istog, Maruševski (2009, str. 11) naglašava da su Kršnjavijeve ideje u sazvučju s intelektualnim i političkim obzorjem Strossmayera koje treba razumijevati kao kontinuirani tok prosvjetiteljskih tendencija. Autorica uspostavlja poveznice između osnovnih idejnih postavki Kršnjavijevog znanstvenog rada i teoretičara arhitekture Gottfireda Sempera. Utjecaj Semperovih pristupa se uočava u interpretaciji porijekla narodne arhitekture i ornamenta. Univerzalne vrijednosti naslijeđa, koje treba sačuvati i prilagoditi suvremenom kontekstu, prepoznaju se $u$ ornamentalnim motivima tradicionalnih tekstilnih i keramičkih proizvoda primijenjene umjetnosti. Referirajući se na ideje Sempera, Kršnjavi posvećuje prva dva desetljeća svog rada organizaciji razvoja umjetničkog obrta koju ujedinjuje u Društvu umjetnosti, Muzeju za umjetnost i obrt, Obrtnoj školi i Katedri za povijest umjetnosti. Propitujući poziciju tradicije unutar historicističkih stilskih odrednica i njeno prilagođavanje suvremenim tendencijama, Kršnjavi u tradiciji prepoznaje temeljnu vrijednost i suštinsku zakonitost kao determinantu historicističkog stila. Naglašava i sposobnost transformacija oblika građevina sukladno promjenama nazora i potreba u određenom povijesnom trenutku, u čemu vidi potencijal za rađanje novih umjetničkih formi. 
U određenju hrvatskog nacionalnog stila, Kršnjavi slijedi ideju o razvoju nacionalnih arhitektonskih stilova u Evropi, baziranom na interpretaciji gotike, kao eminentno nacionalnom stilu. Ovo prvobitno preferiranje gotičkog stila promijenit će se kroz aktualizaciju problema nacionalnog stila 1905. godine s raspravom o gradnji crkve Svetog Blaža u Zagrebu. Dok je Građevinski odbor predlagao bizantski ili romanički stil, Kršnjavi je naklonjen stilu renesansnih obilježja, otvarajući problem kulturnog prostora i formiranja nacija. U renesansnom stilu pronalazi srodnost s hrvatskom umjetnosti kroz procvat dubrovačke književnosti i graditeljstva, izdvajajući imena izvrsnih hrvatskih umjetnika Juraja Dalmatinca i Lucijana Vranjanina, kao školovanih arhitekata.

U procesu afirmiranja narodnog graditeljstva i nacionalnog arhitektonskog stila Kršnjavi se zalaže za snimanje svih vrijednih primjera seoskih kuća kako bi se njihove prostorno-oblikovne karakteristike sačuvale. Maruševski (2009, str. 144) naglašava da su Kršnjavijeva nastojanja bila usmjerena k oživljavanju kućne radinosti i razvijanju umjetničkog obrta, što je kasnije preuzela moderna kao vlastiti program. U tom kontekstu, njegova pionirska terenska istraživanja narodne arhitekture, s ciljem njene suvremene reinterpretacije kroz povezivanje umjetnosti i obrta, prepoznaju se kao osnovni programski koncepti moderne.

Važan poticaj za oblikovanje nacionalnih arhitektonskih stilova i prezentiranje specifičnih etničkih identiteta imale su međunarodne izložbe. Kroz komparativnu analizu postavke izložbe u Budimpešti 1885. godine, Kršnjavi konstatira da postoji srodnost u oblicima ornamentike hrvatskih, srpskih, rumunskih i mađarskih primjeraka narodne umjetnosti. Smatra da su izvori ovih zajedničkih oblika u klasičnoj kulturi evropskih naroda.

Kao primjer reinterpretacije motiva preuzetih iz narodne umjetnosti, Maruševski (2009, str. 146) navodi projekt Hermanna Bolléa za Hrvatski paviljon na izložbi u Trstu 1882. godine, čija drvena konstrukcija, arhitektonski oblici i forme krova ukazuju na uzore u tradicionalnoj kući iz Iloka. Općenito, paviljoni na međunarodnim izložbama u stilu seoskih kuća prezentiraju nacionalne boje, poput posavske drvene kuće u Beču 1873. godine ili nacrt za hrvatski paviljon u Budimpešti 1896. godine.

Ono što povezuje traganja za nacionalnim stilom u Hrvatskoj i fenomen bosanskog sloga jeste predano i studiozno istraživanje graditeljske baštine. 
Paralelizmi se u ovim procesima prepoznaju i u afirmaciji tradicionalne stambene arhitekture. Međutim, dok su u Kršnjavijevom pristupu problematici nacionalnog arhitektonskog idioma prisutna referiranja na historicističke tendencije obnove gotičkih i renesansnih tradicija, arhitektura bosanskog stila je bliža koncepcijama secesije i modernističkim estetskim i oblikovnim principima u kojima se uočavaju podudarnosti s graditeljskim naslijeđem iz osmanskog perioda.

\section{ZAKLJUČNA RAZMATRANJA}

U komparativnom diskursu razvoja nacionalnih arhitektonskih stilova na području Balkana, bosanski slog se izdvaja kao specifična pojava, nastala u međusobnom prožimanju različitih kulturoloških utjecaja. Za razliku od drugih arhitektonskih idioma s nacionalnim obilježjima, bosanski slog nije odraz imperijalne ideologije, odnosno političke instrumentalizacije usmjerene na konstrukciju nacionalnog identiteta, već kreativna reinterpretacija estetskih, prostornih i ambijentalnih vrijednosti tradicionalnih arhitektonskih oblika u suvremenom kontekstu. U poređenju s drugim stilskim orijentacijama, bosanski slog odražava drugačiji koncept u interpretaciji i analizi lokalnog graditeljstva. Evidentno je da on predstavlja autentičnu pojavu čija je važnost višestruka jer ukazuje da arhitektura nije isključivo reprezent etniciteta, već je kreacija univerzalnih vrijednosti izvan prostornih i vremenskih determinacija.

U kontinuitetu razvojnih procesa bosanskohercegovačke arhitekture, bosanski slog je važna poveznica s arhitekturom evropske moderne. Stoga, ovu stilsku odrednicu treba razumijevati kao arhitektonski idiom koji nadilazi okvir nacionalnog stila jer otvara prostor za razvoj i dalja istraživanja u oblasti arhitektonske misli i prakse usmjerene na kritičko propitivanje tradicionalnih arhitektonskih oblika. Pitanje sinteze tradicije i modernosti koje problematizira arhitektura bosanskog sloga ima svoj kontinuitet u modernističkim i postmodernističkim reminiscencijama naslijeđenih graditeljskih formi, što potvrđuje njihov vitalitet i mogućnost transformacije. 


\section{LITERATURA}

Baotić, A., 2012. "Orijentalizam u prikazima Bosne i Hercegovine pod austrougarskom upravom na međunarodnim i svjetskim izložbama”. U: Sophos, 5, str. 107-130.

Hrasnica, M., 2003. Arhitekt Josip Pospišl - život i djelo. Sarajevo: Acta arhitectonica et urbanistica, Arhitektonski fakultet u Sarajevu.

Ignjatović, A., 2016. U srpsko-vizantijskom kaleidoskopu: arhitektura, nacionalizam i imperijalna imaginacija 1878-1941. Beograd: Orion art i Univerzitet u Beogradu, Arhitektonski fakultet.

Kadijević A., 2016. Vizantijsko graditeljstvo kao inspiracija srpskih neimara / Byzantine architecture as inspiration for serbian new age architects. Beograd: Srpska akademija nauka i umjetnosti.

Krzović, I., 2004. Arhitektura secesije u Bosni i Hercegovini. Sarajevo: Sarajevo publishing.

Kurto, N., 1998. Arhitektura Bosne i Hercegovine, razvoj bosanskog stila. Sarajevo: Sarajevo Publishing.

Maruševski, O., 2009. Iso Kršnjavi kao graditelj: izgradnja i obnova obrazovnih, kulturnih i umjetničkih objekata u Hrvatskoj II. Nadopunjeno izdanje. Zagreb: Društvo povjesničara umjetnosti SR Hrvatske.

Vancaš, J., 1928. "Bosansko narodno graditeljstvo". Tehnički list X, br. 24, 31. 12, str. 353-356.

Veselinović, D. Zirat banka u Ankari simbol nacionalnog preporoda. Dostupno na: http://www.orbis-ns.com/arhitektura-id.php?id=37 [22. 11. 2020]. 


\title{
BOSNIAN STYLE IN THE COMPARATIVE DISCOURSE OF NATIONAL ARCHITECTURAL STYLES IN THE BALKANS
}

\begin{abstract}
Summary
The article analyzes the Bosnian style in architecture by reflecting upon the phenomenon of the national architectural style, its role in the construction of national identity, political and ideological instrumentalization. The issue of the relationship between tradition and modernity and the position of architectural heritage in the contemporary context arises. Interpretative framework of the specificity of the national architectural idiom also includes a discursive view of the relationship between the periphery and the center. Through a comparative analysis of national styles in architecture of the Balkan countries such as Bosnia and Herzegovina, Turkey, Croatia and Serbia, their character, distinction and mutual connections are defined. The Bosnian-style in architecture is viewed in its development as an architectural idiom of the national origin, but also as an authentic stylistic determinant created in the process of a creative research of architectural heritage that will ultimately result in new spatial-design and aesthetic values consistent with modernist architectural concepts. In this sense, the position of the Bosnian style as a national style in the history of European modernism is questioned, its connection with the aesthetics of modernism based on the principles of reducing excessive decorativeness, formative purism and functionalism.
\end{abstract}

Key words: Bosnian style, national architectural style, Serbian-Byzantine style, modernism, tradition, First national architectural movement, national identity 